\title{
CORRIGENDUM
}

\section{Effects of valsartan and amlodipine on home blood pressure and cardiovascular events in Japanese hypertensive patients: a subanalysis of the VART}

H Takano, H Hasegawa, H Narumi, S Shindo, H Mizuma, Y Kuwabara, Y Kobayashi and I Komuro on behalf of the VART investigators

Journal of Human Hypertension (2013) 27, 580; doi:10.1038/jhh.2013.58

Correction to: Journal of Human Hypertension (2012) 26, 656-663; doi:10.1038/jhh.2011.91; published online 13 October 2011

The authors would like to correct the affiliation of Nobuo Shirahashi, who was included in the acknowledgements.

Therefore, the last sentence of the acknowledgements:
'Statistical analysis organization: Nobuo Shirahashi (Clinical Epidemiology, Osaka City Graduate School).'

Should read: 'Statistical analysis organization: Nobuo Shirahashi (Novartis Pharma KK).' 


\section{RETRACTION}

\section{Effects of valsartan and amlodipine on home blood pressure and cardiovascular events in Japanese hypertensive patients: a subanalysis of the VART}

H Takano, H Hasegawa, H Narumi, S Shindo, H Mizuma, Y Kuwabara, Y Kobayashi, I Komuro on behalf of the VART investigators

Journal of Human Hypertension advance online publication, 2 October 2014; doi:10.1038/jhh.2014.90

Retraction to: Journal of Human Hypertension (2012) 26, 656-663; doi:10.1038/jhh.2011.91; published online 13 October 2011

The paper has been retracted due to concerns raised by the publishing institution regarding problems with management of conflicts of interest and with the reliability of the published data. 